\title{
LIMITED GENDER KNOWLEDGE OF ELEMENTARY SCHOOL'S TEACHERS :A CASE STUDY OF 20 TEACHERS OF SDN 28 DAN 43 RAWANG TIMUR PADANG, WEST SUMATERA)
}

\author{
Selinaswati \\ Sociology Department, Faculty of Social Sciences Universitas Negeri Padang \\ E-mail :selinaswati@,fis.unp.ac.id
}

Diterima : 2 Agustus 2018

Direvisi : 21 Oktober 2018

Diterbitkan: 31 Desember 2018

\begin{abstract}
This research aims to describe the lack of gender knowledge of 20 teachers in two primary schools in Padang. It is assumed that teachers in primary schools are important to have gender knowledge. This is because primary schools is the basic education for pupils in building their character and constructing their mindset, especially mindset with gender awareness and gender sensitivity attitude. Thus teachers without gender bias and lack of gender knowledge plays an important role for widely spread the gender sensitivity and gender awareness in order to fight the bias gender and discrimination against women. The research takes qualitative method by using indepth interview and distribute questioner toward 20 teachers in 2 primary schools. The result showed that most teacher in these two primary schools have lack of knowledge about gender concept and kind of difficult to make different among the definition of sex and gender concept. This lack of knowledge to some extent affected the learning process with several gender biases in facing their pupils in the school activities. It is recommended in increasing the socialization process of gender knowledge around primary school's teachers.
\end{abstract}

Keyword: Gender, knowledge, elementary school.

\begin{abstract}
Abstrak
Penelitian ini bertujuan untuk mendeskripsikan kurangnya pengetahuan gender dari 20 guru di dua sekolah dasar di Padang. Diasumsikan bahwa guru di sekolah dasar penting untuk memiliki pengetahuan gender. Ini karena sekolah dasar adalah pendidikan dasar bagi siswa dalam membangun karakter mereka dan membangun pola pikir mereka, terutama pola pikir dengan kesadaran gender dan sikap sensitivitas gender. Jadi guru tanpa bias gender dan kurangnya pengetahuan gender memainkan peran penting untuk menyebarkan kepekaan gender dan kesadaran gender secara luas untuk melawan bias gender dan diskriminasi terhadap perempuan. Penelitian ini menggunakan metode kualitatif dengan menggunakan wawancara mendalam dan mendistribusikan kuesioner kepada 20 guru di 2 sekolah dasar. Hasil penelitian menunjukkan bahwa sebagian besar guru di kedua sekolah dasar ini kurang memiliki pengetahuan tentang konsep gender dan agak sulit untuk membedakan antara definisi jenis kelamin dan konsep gender. Kurangnya pengetahuan sampai batas tertentu mempengaruhi proses pembelajaran dengan beberapa bias gender dalam menghadapi muridmurid mereka dalam kegiatan sekolah. Disarankan dalam meningkatkan proses sosialisasi pengetahuan gender di sekitar guru sekolah dasar.
\end{abstract}

Kata kunci: Gender, pengetahuan, sekolah dasar.

\section{Introduction}

Having less knowledge about gender may bring an impact on discrimination against women. This discrimination is still widespread across the country; whether in both of developing or developed countries; it is happened continuously and become a global problem ${ }^{1}$. Recently, there have been a number of government agencies and nongovernmental organizations (NGOS) focused on reducing these gender issues. However, these efforts have shown unfulfilled results.

${ }^{1}$ Saparinah Sadli, (2010), Berbeda tetapi Setara; Pemikiran tentang Kajian Perempuan, Jakarta:Kompas,h.34 
This can be seen from the many cases of discrimination that have occurred, especially related to violence against women. Data from the Commission on Women's Rights (KomnasPerempuan) $^{2}$, there is an increasing number violence against women around $74 \%$ from 2016 to 2017. Compared to data collected in 2016, the cases of violence against women are 259,150 cases and in 2017 became 348,446 cases.

Commission on Women's Rights (KomnasPerempuan) also revealed that most cases are domestic violence or in a personal area that is 9,609 cases (71\%) of physical, sexual, psychological and physical abuse. The next case in the violence in the public area is $3,528(26 \%)$ in the form of rape, obscenity, harassment, criminal cases and media violence. Last, violence against women happened in the level of state atmosphere (the state seems to ignore women's right in the form of local evictions- penggusuran) has up to 217 (1.8\%). The increasing number of discrimination can be said as a mirror of society whose have not enough gender sensitivity to prevent the discrimination and violence against women.

Based on the increasing number of violence, it can be said that the discrimination against women are still existed in many levels of society. Therefore, gender sensitivity or critical attitude towards gender discrimination is required in order to raise gender awareness and to diminish the gender discriminations. Gender-sensitive attitudes should not only be owned by policy makers in the government level, or among women activists itself but also from non-government, activist and observers of gender issues and public figure in the community. Gender-sensitive attitudes should also being a part of teachers, especially teachers in primary school. This is because

${ }^{2}$ Komnas HAM Perempuan (2018), Catatan Tahunan (Catahu) Komnas Tergerusnya Ruang Aman Perempuan dalam Pusaran Politik Populisme, Jakarta: Komnas Perempuan, h.1 teachers as educators become role models for their students. In line with the name of primary or elementary schools, this school level is a basic place and becoming the first step for children not only for getting formal education that affected their mindset but also for building their character bassically.

As teachers play an important role to transfer knowledge, to build students' character, and to be role models for their students, it is important to give the teachers gender knowledge so that they can be gender sensitive. By having gender sensitivity, the teachers in Primary school in Padang (SD) can easily transfer the idea about gender issues. They may implement their gender knowledge through their learning process in the class to the pupils. It can be said that having gender knowledge and transferring it to the pupils is important. This is because the pupils can absorb the gender knowledge in order to be people with gender awareness and will have mindset justice and will no longer preserve the patriarchy mindset. This article describes and analyzes the knowledge of teachers in two primary schools (SD) on their understanding of gender concepts. It also analyzes the effects of such ignorance on their sensitivity to gender, particularly in the way they teach and transfer knowledge in teaching and learning process.

\section{Method}

The research methodology in this article takes qualitative descriptive ${ }^{3}$. The collection of the data is done in two ways. The first by distributing questionnaire addressed to 20 teachers, consisting of three male teachers and seventeen female teachers. These 20 teachers come from two public elementary schools which totally have 24 teachers including 15 teachers from elementary school of 28 (SDN 28) which consisting of 13 female

3J.W. Creswell, 2013, Qualitative Inquiry \& Research Design third edn, SAGE, Los Angeles. 
teachers and 2 male teachers. Next SDN 43 with 9 teachers consists of one male teacher and 8 female teachers. The unequal composition of teachers between the sexes male and female is clearly seen in these two primary schools. This reality also happened in many primary schools in Padang; mostly male teachers teach sports lesson and teach Islamic religious education. The rest of the teachers are female teaching who taught various subjects. The second, is using in-depth interview (in-depth interview) toward 5 teachers in two elementary schools consisting of 4 female teachers and one male teachers.

\section{Conceptual Framework}

It has been known that gender and sex are two different things but strongly connected each other. Because of that, some people seems to be misunderstood pertaining to both defenition of sex and gender. Even though these two concepts are connected, but it did not synonym ${ }^{4}$. As Fakih stated that gender is a social construction, determined the roles of male and female throughout social interaction; because of that the gender role may be able to be different in different time and different places and these roles do not a permanent but can be exchanged ${ }^{5}$. According to American Psychological Association ${ }^{6}$, sex refers to a person's biological status and is typically categorized as male or female while

${ }^{4}$ Amanda Tomkins et all, Gender Influences on Students Study Abroad Participation and Intercultural Competence, journal of Student Affairs Research and Practice, 54(2), h.204-216.

${ }^{5}$ Mansour Fakih, 2006, Analisa Gender ※TransformasiSosial; Yogyakarta: penerbitPustakaPelajar h. 9

${ }^{6}$ American Psychological Association. (2011).Guidelines for psychological practice with lesbian, gay, and bisexual clients:Definition of terms. Retrieved from http://www.apa.org/pi/lgbt/resources/sexualitydefinitions.pdf June 22, 2018 gender refers to the attitudes, feelings, and behaviors that given culture associate with a person's biological sex. Thesetwo different concepts tend to be misunderstood by many people. This also can be seen through some teachers in primary schools in many provinces in Indonesia. This condition leads to a lack of gender awareness and affects gender sensitivity and neglect of gender inequality. As a result, gender discrimination exists in many different places and different layers of society. Some effort have been done by Indonesian government such as already enacted the Convention on the Elimination of Discrimination Against Women (CEDAW) since 1984. It has ratified through several programs such as Gender Equality (Pengarusutamaan Gender). This program aims to drawn all of public policies regarding women and children's life with gender issues. Additionally, there is a formal government institution which is called the Ministry of Empowerment and Children's Women (Anak Dan PerempuanKementraPemberdayaan - KPPA, formerly called the Ministry of Empowerment of Women, Women's Roles), aims to diminish discrimination against women.

Not only government institutions, non-governmental institutions also active and involve in reducing discrimination against women. This can be seen through some nongovernmental organizations in Indonesia, such as the National Women's Rights Committee (KomnasPerempuan) and the Women's Crisis Center (WCC) and other local NGOs, focusing on women's issues. Furthermore, we already know that the school with its elements plays an important role in enhancing the character of students and prepares them to face their future. Primary schools are the place where children build their first attitude. These schools become space also to communicate with certain values that have influenced their way of thinking. However, there are many people who hold the patriarchal way of 
thinking that there is a tendency to discriminate against women, including primary school teachers. On this basis, it is important to increase the sensitivity of teachers in order to broaden the knowledge of gender, reduce discrimination against women and convey the true concept of gender especially learning process.

\section{The Ambiguous of Gender Concept}

This research found that the gender knowledge of primary school teachers are diverse and tends to have less knowledge about gender. When teacher were asked for the term of gender, 17 people $(85 \%)$ already know the term of gender previously, while 3 people $(15 \%)$ admitted they have not heard the term gender before. More detail questions about from where they know the word or the term of gender, of 17 teachers 9 of them $(53 \%)$ answered that they knew about this word from mass media online, including television and radio, while 3 people (18\%) claimed to obtain information during seminars, counseling or socialization. The same amount, 3 people claimed to know the gender word from colleagues or other teachers. The other two people respond they heard the word gender incidentally by hearing or seeing the term through casual or occasional conversations in an informal atmosphere and by filling out forms in English that include 'gender' and then they will get instruction to thick male or female.

Variable responses are also observed when 17 people are asked how long it takes to know the term or the word gender; the finding showed that 9 people $(53 \%)$ responded have known the term gender for more than 4 years, even a teacher who is 41 already knows since college, which means she already knows more than a dozen years ago. Then less than 5 teachers $(30 \%)$ answered that they knew the term gender within 2 to 4 years. Next there are 2 teachers $(12 \%)$ responded to know the gender for less than a year. Interestingly, when the concept or definition of gender was asked, there are 10 teachers $(59 \%)$ respond that gender is refers to biology, something common related to male and female. Next there are 7 teachers (41\%) answered exactly that definition of gender, such as gender is the different roles among male and female due to the socio-cultural construction of local communities. The next question about God's will toward 20 teachers. It is found that 16 teachers say Godwill is a God's irreversible provisions. One mentions that God's will is a God's destiny to people and there are 3 teachers answered that all of irreversible provision can be changed.

Based on that situation, it can be analyzed that on the one hand, ambiguous conceptions is understandable. This is because teachers in the research area as well as their community growth and learnt how they are socializing with values that dichotomy the roles of men and women. These bias genders within communities have become tradition to build constructions those men and women have separate roles (who tend to be in the public sector) with women's roles (mainly in the domestic sector) ${ }^{7}$. It is common that the different roles among men and women raises and leads to limit opportunities for women to participate in the public sector. This also tends to preserve the patriarchal mindset. Of course it will not be a problem if it does not create imbalances, but on the contrary, the idea of patriarchy has dominated; and so much marginalize and discriminate women.

Societies can be said have tradition to build constructions that cause men and women are having separate roles. It is common to find of men (who tend to be in the public sector) with women's roles (mainly in the domestic sector). It will not be a

${ }^{7}$ Mansor Fakih, (2006), Analisa Gender ※Transformasi, h.11 
problem if it does not create imbalances, but on the contrary, the idea of patriarchy has marginalized and discriminated against women. This situation to some extent provides the different roles that may bring a bad impact on women when they want to involve in the public space. They have double burden or even triple burden. These burdens are a mirror of how the gender bias affected women and directly connected with the gender bias and less gender knowledge.

The ambiguous of gender knowledge and bias definition of gender concept by influential educators will ultimately lead to gender discrimination experienced by students. When this happens, of course, this is not good, especially when the teachers transfer of knowledge to students such as (something common in the many primary schools) introduce students how to write correctly. They also teach students to read fluently, count correctly and appropriately for the first time. Thus, an understanding of the concept of gender should be implemented by teachers in primary school to meet the target of education as learners who have a basic knowledge of gender-sensitive attitudes.

It is undeniable that schools are the second institution to educate and shape the character of children after the institution of the family; that the goal of humanizing human education began when primary school-aged children are confidently handed over by their parents to an educational institution called elementary school (SD). Primary school as an educational institution is an organization made up from a number of norms, values of rules and people. Furthermore, school has three functions in order to meet their education goal with gender sensitivity attitude including $\left.{ }^{8} 1\right)$ to implement the gender equality in the schools and reduce the discriminations among pupils, 2) to create

${ }^{8}$ KhusnulKhotimah, UrgensiKurikulum Gender dalamPendidikan. INSANLA, Vol.13.No.3, 2008, 420533 gender equality among teachers and people in this primary schools, 3) to reduce the elements that can cause violence and discrimination throughout transferring knowledge and fight for negative stereotype the lack of knowledge about gender and gender-specific attitudes among educators needs to be addressed as they are influenced by the state of mind they already have. Indeed, the distinction of roles between men and women is not a problem; it is only a matter of knowing when these differences in roles lead to gender inequality or gender discrimination.

\section{Gender Bias in the Learning Process}

The lack of knowledge of most teachers in these two elementary schools, to some extent, had an impact on the learning process of students. The research found that the teachers tend to have gender bias in their teaching style. Of 20 teachers, 12 agree that the reality of differences among boys and girls as pupils are needed to pay attention, especially in choosing the chair in the class and in dividing them when doing class activity. Pertaining to select the chair in the class, it was found that these teachers consider chairman instead of chairwomen. Instead of choosing a girl as a chair, they prefer to choose boys

Pertaining to the gender differences in the class, out of 20 teachers, 3 teachers abstain did not have any opinion and only 5 teachers seriously mentioned that it is common and it is not a problem when they found male and female students in the class. This different gender did not dilemma for them in doing class activities. These 5 teachers gave them some instruction did not based on gender but based on students capacities and capabilities.

Another comparison also can be seen through the question of which pupils in the class have problems during classroom study. These problems can be identified in terms of pupils' compliance in the classroom, discipline and meticulously in the classroom. Of 20 
teachers, 18 of them recognized that boys are more difficult to be organized in the class. Nevertheless their experiences tend to showed that the boys dare to appear in front of the class. As mentioned by one of teacher:

“.. Teaching on subject
matter to pupils in
elementary school is more
difficult than giving
lessons to students in
junior or high school or
even university. We must
be expressive in delivering
of the subject in front of
the class; otherwise they
tend to do not focus on
seeing us. Based on my
experience, it seems
harder to teach primary
school students than
universities because we
must be more
expressive.."

The statement above showed the reality and the experiences of one of teachers whose teach the Primary School students. This is not easy; they must have different strategy such as having good communication that can be easily understood by pupils. Not only more expressive in delivering the subject, they also must be aware to the content of the lesson and the emotional growth of pupils as teenagers. As stated by one of teachers who teach Biology Subject in sixth grade:

"...In the Grade 6
Biology class, we
separated the learning
hours of boys and girls
because there was a topic
pertaining to the
physically appearance of
women and men. When
the teenagers were

${ }^{9}$ Interview with Pak Suhatril, one of male teachers, Saturday, 6 Agustus 2016 learning this lesson, especially concerning the body organ and genitals of men and women these boys and girls are giggling. This made them did not focus on the lesson. Thus we decide to separate them..." 10

The statement above kind of interesting since there is a decision to have a separate class. It does not mean that they did discrimination. Nevertheless, they have some consideration that the targets (learning process run smoothly and the pupils learning completely) must be reached. This situation can be seen in two different views. In one side, the separation class among boys and girls during Biology lesson may say as a different treatment among boys and girls in these two Primary schools. In another side the separation class among boys and girls aims to meet the lesson's target. Based on that situation, it may say that the differences among boys and girls cannot be seen as a gender bias completely. This is because psychologically these adolescences need favorable atmosphere for learning and this situation is found by teaching them separately.

The bias gender in learning process clearly has to avoid. Nevertheless, to some extent some issues hampered this learning process could be solved by giving the gender knowledge and clearly different concept of sex, gender and God's will toward some teachers in primary schools.

\section{Conclusion}

The discrimination issues that arise in the community are closely linked to sensitive or gender-sensitive attitudes. The lack of gender knowledge and less gender-sensitive

${ }^{10}$ Interview with Ibu M, one of female teachers, Saturday, 6 August, 2016) 
attitude in the different layers of society, at least can be reduced by giving some information pertaining to tehse concept and knowledge toward teachers in primary schools. When society tends to perpetuate the tradition of conceptual prejudices and gender roles, it is also transmitted to educational institutions. Like the different roles represented in textbooks; teaching materials at the primary school level tend to be biased towards gender. As in textbooks, it shows the differentiation or dichotomy between the role that men share and the role women play. The socio-cultural construction of a gender-based society in educational institutions, especially at the primary school level, seems to be visible throughthe materials

Admittedly, it takes a long time to bring about this sensitive or gender-sensitive attitude. Because during the years of reality that have been visible, it is always the number of women who become discriminated against because the construction of the socio-cultural community has formed a state of mind and a state of mind that defines the role women like that. This way of thinking tends to be patriarchal, so that sometimes the discrimination that occurs in the community emerges unconsciously and is so entrenched that it is difficult to change

\section{References}

Amanda Tomkins et all, Gender Influences on Students Study Abroad Participation and Intercultural Competence, Journal of Student Affairs Research and Practice, 54(2), h.204-216

American Psychological Association. (2011).Guidelines for psychological practice with lesbian, gay, and bisexual clients: Definition of terms. Retrieved from
file:///D:/Artikel\%20gender/Gender sensiti vity'Influences on Students'.pdf June 22, 2018

KhusnulKhotimah, UrgensiKurikulum Gender dalamPendidikan . INSANIA, Vol.13.No.3, 2008, 420-533

J.W. Creswell, 2013, Qualitative Inquiry \& Research Design third edn, SAGE, Los Angeles.

Komnas HAM Perempuan (2018),Catatan'Tahunan (Catahu) Komnas'TergerusnyaRuang Aman PerempuandalamPusaranPolitikPopulis me, Jakarta: KomnasPerempuan, h.1

Mansour Fakih, 2006, Analisa Gender \&TransformasiSosial; $\quad$ Yogyakarta: penerbitPustakaPelajar

SaparinahSadli, (2010), BerbedatetapiSetara; Pemikirantentang Kajian Perempuan, Jakarta:Kompas,h.34

Suhatril, personal interview, Saturday 6 August 2016

Maidarni, personal interview, Saturday 6 August 2016 